\title{
EFFECT OF FINANCIAL PERFORMANCE, DER, DP, COMPANY SIZE ON COMPANY VALUE ON FOOD AND BEVERAGE SECTOR
}

\author{
Bayu Wulandari ${ }^{1)}$,Yohana Meilinita Napitupulu ${ }^{2)}$, Naisy Margareta Lentina Cibro ${ }^{3)}$, \\ Desnita Masriani Br. Sembiring ${ }^{4)}$, Angel Marselin Sarumaha ${ }^{5 *}$ \\ 1,2,3,4,5 Universitas Prima Indonesia \\ Email: angelsarumaha11@gmail.com
}

\begin{abstract}
This study aims to examine the effect of Financial Performance, DER, Dividend Policy, Current Ratio, Leverage, Company Size on firm value. This research was conducted on manufacturing companies in the food and beverage sub-sector for the $2018-\mathrm{u} 2020$ period with a population of 33 companies listed on the Indonesia Stock Exchange. The data used are the financial statements of each sample company published on the website www.idx.co.id. The research method used is descriptive analysis method and multiple linear regression analysis method. The dependent variable is firm value, while the independent variables are financial performance, DER, dividend policy, current ratio, leverage and firm size. The results of this study indicate that partially financial performance, DER, dividend policy, current ratio, leverage, firm size have an effect on firm value, but firm size has a significant effect on firm value.
\end{abstract}

Keywords: Financial Performance, DER, Dividend Policy, Current Ratio, Leverage, and Company Size

\section{INTRODUCTION}

Every company that is established has a goal to generate corporate value through increasing shareholder wealth. An increase in company value will affect shareholder value if the increase is marked by a high rate of return on investment to shareholders[1]. Firm value is an investor's perception of the company which is often associated with stock prices. Measurement of financial performance is one of the indicators used to assess a company from the stock price on the Indonesian stock exchange. In addition, the size of the company is one of the benchmarks that shows the size of the company is the total assets of the company[2]. Total assets describe all the resources owned by company that can be used for company operations[3].

Increased profitability of the company can affect the value of the company. This depends on how investors perceive the company's profitability to increase. A company in the use of leverage will affect changes in the value of the company up or down[4]. The use of high debt for corporate capital will increase the value of the company because the use of debt can save taxes[5].

The amount of dividends distributed by the company can affect the stock price which makes investors prefer to take dividends[6]. Debt policy is a policy carried out to fund operations using financial debt. Companies with higher debt 
levels can increase earnings per share and also increase company value[7].

Table 1. Research Phenomenon[8]

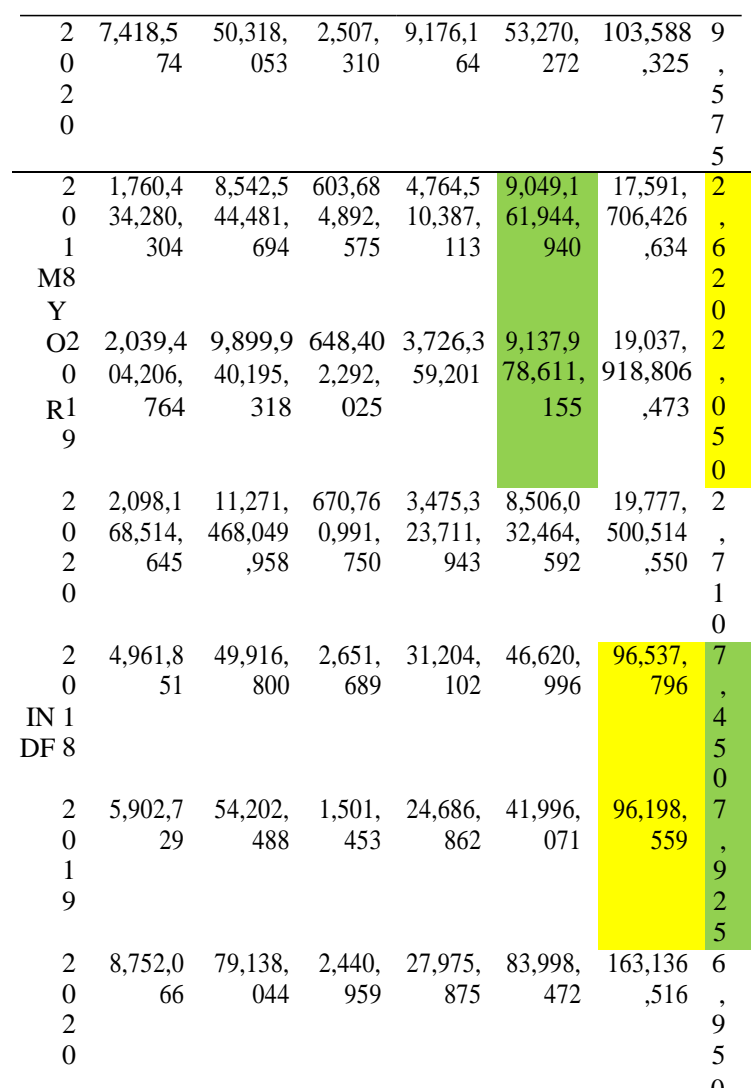

The table above shows that the fluctuation data at PT. Budi Starch \& Sweetener Tbk, the percentage of total net income in 2019 and 2020 decreased by Rp. 3,042 and the percentage of share prices in 2019 and 2020 decreased by Rp. 4. This phenomenon is contrary to the existing theory, namely if financial performance increases, the share price distributed will increase. will decrease. In table above, it can be seen that the fluctuation data at PT. Delta Djakarta Tbk the percentage of total equity in 2018 and 2019 decreased by Rp. $70,600,492$ and the percentage of share prices in 2018 and 2019 increased by Rp.
1,300. This phenomenon is contrary to the existing theory, namely if the total equity increases then the share price distributed will also increase[9].

In table above, it can be seen that the fluctuation data at PT. Sekar Laut, Tbk the percentage of dividends in 2019 and 2020 increased by Rp. 3,729,998,700 and the percentage of share prices in 2019 and 2020 decreased by Rp. 45. This phenomenon is contrary to the existing theory, namely if dividends increase, the share price distributed will also increase. increase. In table I.I. above, it can be seen that the fluctuation data at PT. Indofood CBP Sukses Makmur Tbk, the percentage of total current liabilities in 2018 and 2019 decreased by Rp. 679,039 and the percentage of share prices in 2018 and 2019 increased by Rp. 700. This phenomenon is contrary to the existing theory, namely if total current liability increases, the share price will increase. shared will also increase[10].

In table. above, it can be seen that the fluctuation data at PT. Mayora Indah, Tbk the percentage of total debt in 2018 and 2019 increased by Rp. 88,816,666,215 and the percentage of share prices in 2018 and 2019 decreased by Rp. 570. This phenomenon is contrary to the existing theory, namely if the total equity increases then the share price distributed will also increase. In table I.I. above, it can be seen that the fluctuation data at PT. Indofood Sukses Makmur Tbk, the percentage of total assets in 2018 and 2019 decreased by Rp. 339,237 and the percentage of share price in 2018 and 2019 increased by Rp. 475. This phenomenon is contrary to the existing theory, namely if total assets

Submitted : 14/10/2021 - Accepted : 10/12/2021 - Published : 11/12/2021 
increase, the share price distributed will also increase. Increase[13].

\section{RESEARCH METHODS}

This study uses quantitative analysis methods because the data are in the form of numerical and empirical data. While the selected variables are in the form of units that can be calculated and measured. This analysis method uses software tools from SPSS to parse the results of the calculation of the tests used such as the classical assumption test and multiple linear regression.

The research approach used in this research is quantitative research. Quantitative research is research whose data is in the form of numbers and analyzed using numeric

The type of research used is descriptive quantitative research. Quantitative descriptive problem formulation is a problem formulation that contains a statement about a state of independent variables, either one or more variables (stand-alone variables).

This research is explanatory. Explanatory research is research that aims to analyze causal relationships between variables by testing hypotheses in order to strengthen or reject the hypothesis of existing research results.

In this research, the data analysis method used is the statistical analysis method. Before analyzing the data, the classical assumption test was carried out first before testing the hypothesis. Data analysis in processing data using SPSS (Statistical Product and Service Solution).
This data analysis model uses multiple regression analysis to determine the effect of the independent variable (independent) and the dependent variable (dependent). Multiple linear regression analysis formula is used as follows:

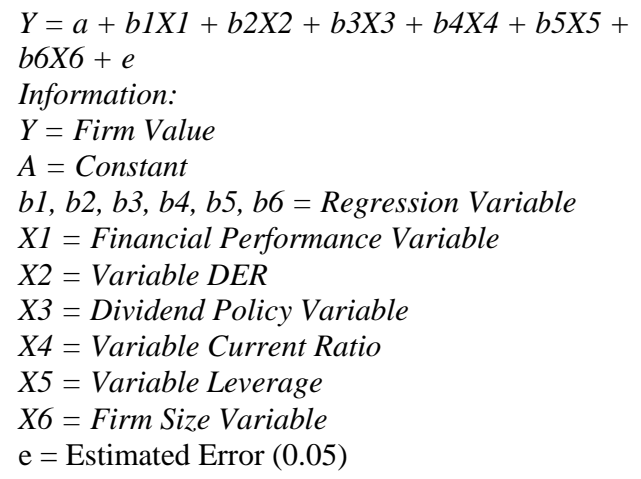

To test this hypothesis, the F statistic is used with decision making criteria that compares the calculated $F$ value with the $F$ value according to the table, namely:

a) accepted or rejected if and sig value $>0.05$

b) accepted or rejected if $>$ and sig value $<0.05$

\section{RESULTS AND DISCUSSION}

The sample $(\mathrm{N})$ used in this study is the financial statements of manufacturing companies in the food and beverage sector that are listed on the BEIu in $2018-\mathrm{u}$ 2020[14].

Table 2. Decriptive Statistic

\begin{tabular}{|c|c|c|c|c|c|}
\hline & $\mathrm{N}$ & $\begin{array}{l}\text { Mini } \\
\text { mum }\end{array}$ & $\begin{array}{l}\text { Maximu } \\
\mathrm{m}\end{array}$ & Mean & $\begin{array}{c}\text { Std. } \\
\text { Deviation }\end{array}$ \\
\hline $\begin{array}{l}\text { Kinerja } \\
\text { Keuangan }\end{array}$ & & 3,014873946 & ,222874337 & , 0885 &, 05346 \\
\hline DER & & 3,134233320 & 1,766428262 & ,6147 & ,44032 \\
\hline $\begin{array}{l}\text { Kebijakan } \\
\text { Dividen }\end{array}$ & & 3,000002999 & 62,500000000 & 7,2844 & 15,84317 \\
\hline Current Ratio & & $\begin{array}{r}1,00315637 \\
1\end{array}$ & 47,997190443 & 5,2095 & 8,31886 \\
\hline Leverage & & 3,115157576 & 6,372421907 & ,5119 & 1,06357 \\
\hline $\begin{array}{l}\text { Ukuran } \\
\text { Perusahaan }\end{array}$ & & $\begin{array}{r}12,7366420 \\
7\end{array}$ & 30,61556607 & 23,4034 & 5,81883 \\
\hline
\end{tabular}

Submitted : 14/10/2021 - Accepted : 10/12/2021 - Published : 11/12/2021

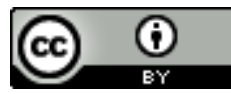


$\begin{array}{lllll}\text { Nilai } & 00039 & 002 & 000000000 & 00018864443\end{array}$

Perusahaan

Valid N 33

(listwise)

Table shows the maximum, minimum, mean and standard deviation of the financial performance variables, der, dividend policy, current ratio, leverage, and company size to firm value, as follows:

The financial performance variable has a sample of 33, with a minimum value of 0.014873946 , namely PT. Budi Starch \& Sweetener Tbk in 2018 and a maximum value of 0.222874337 , namely PT. Delta Djakarta Tbk in 2019. And the mean value is 0.0885 and the standard deviation is 0.05346 .

The der variable has a sample of 33, with a minimum value of 0.134233320 , namely PT Campina Ice Cream Industry Tbk in 2018 and a maximum value of 1.766428262, namely PT Budi Starch \& Sweetener Tbk in 2018. Including a mean value of 0.6147 and standard deviation of 0.44032 . The dividend policy variable has a sample of 33 , with a minimum value of 0.000002999 , namely PT Budi Starch \& Sweetener Tbk in 2018 and a maximum value of 62.500000000 , namely PT. Wilmar Cahaya Indonesia Tbk in 2019. Include a mean value of 7.2844 and a standard deviation of 15.84317 .

The current ratio variable has a sample of 33, with a minimum value of 1.003156371, namely PT. Budi Starch \& Sweetener Tbk in 2018 and a maximum value of 47.997190443 namely I PT. Wilmar Cahaya Indonesia Tbk in 2019.
Include a mean value of 5.2095 and a standard deviation of 8.31886 .

The leverage variable has a sample of 33, with a minimum value of 0.115157576 , namely PT. Campina Ice Cream Industry Tbk in 2020 and a maximum value of 6.372421907, namely PT Budi Starch \& Sweetener Tbk in 2018. The mean value is 0.5119 and the standard deviation is 1.06357 .

The company size variable has a sample of 33, with a minimum value of 12.73664207, namely I PT. Budi Starch \& Sweetener Tbk in 2018 and a maximum value of 30.61556607, namely PT. Mayora Indah Tbk in 2020. Include a mean value of 23.4034 and a standard deviation of 5.81883. The company value variable has a sample of 33 , with a minimum value of 0.0000000048 , namely PT. Mayora Indah Tbk in 2019 and the maximum value is 0.00018864443 , namely I PT. Indofoodu Sukses Makmur Tbk in 2018. And the mean value is 0.0002 and standard deviation is 0.00039 .

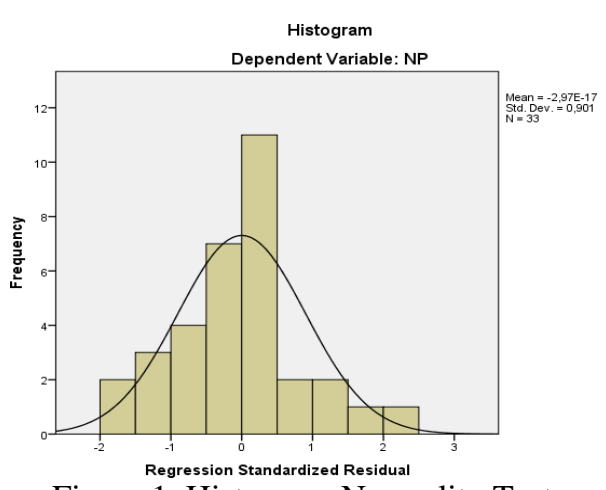

Figure 1. Histogram Normality Test

In Figure above, it can be seen that the curve is skewed symmetrically (U) so it

Submitted : 14/10/2021 - Accepted : 10/12/2021 - Published : 11/12/2021

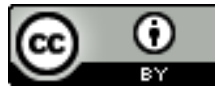

This work is licensed under a Creative Commons Attribution 4.0 International 
can be concluded that the data is normally distributed.

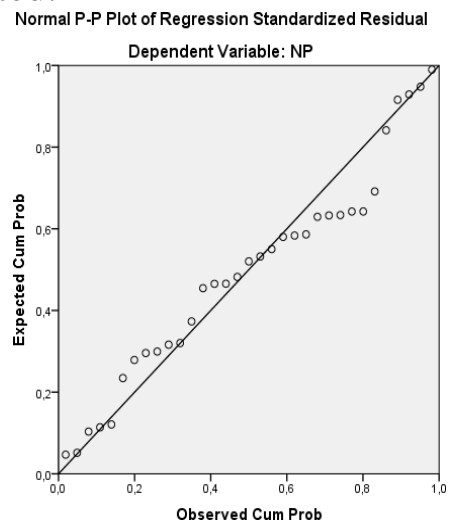

Figure 2. P-P Plot Normality Test

It can be seen that the scattered points follow the direction of the diagonal line so that it can be concluded that the data above is normally distributed.

In addition, to test whether the data is normally distributed, the non-parametric Kolmoglav Smirnov test can be used, which means that if the significance value is $>0.05$, it is declared normally distributed and if the significance value is $<0.05$, it can be declared abnormally distributed.

\begin{tabular}{llr}
\multicolumn{2}{c}{ Table 3. One-Sample Kolmogorov-Smirnov Test } \\
\hline & & $\begin{array}{c}\text { Unstandardized } \\
\text { Residual }\end{array}$ \\
& & 33 \\
$\mathrm{~N}$ & Mean &, 0000000 \\
Normal Parameters ${ }^{\mathrm{a}, \mathrm{b}}$ & Std. &, 00026922 \\
& Deviation &, 161 \\
& Absolute &, 161 \\
Most Extreme & Positive &,- 086 \\
Differences & &, 925 \\
& Negative &, 360 \\
Kolmogorov-Smirnov Z & & \\
Asymp. Sig. (2-tailed) & & \\
\hline
\end{tabular}

Table shows the test results of financial performance variables (X1), der (X2), dividend policy (X3), current ratio (X4), leverage (X5), firm size (X6) on profitability (Y) are normally distributed because the significant value is $0.360>0$ , 05 .

\begin{tabular}{|c|c|c|c|}
\hline \multirow{2}{*}{\multicolumn{2}{|c|}{ Model }} & \multicolumn{2}{|c|}{ Collinearity Statistics } \\
\hline & & Tolerance & VIF \\
\hline \multirow{6}{*}{1} & Kinerja Keuangan &, 614 & 1,627 \\
\hline & DER & ,434 & 2,306 \\
\hline & Kebijakan Dividen &, 545 & 1,835 \\
\hline & Current Ratio & ,557 & 1,796 \\
\hline & Leverage & ,601 & 1,663 \\
\hline & Ukuran Perusahaan & ,628 & 1,592 \\
\hline
\end{tabular}

In table it can be seen that the tolerance value with financial performance variables, der, dividend policy, current ratio, leverage and company size u 0.10 while the VIF value with financial performance variables, der, dividend policy, current ratio, leverage and company size 10 so it can be concluded that there is no multicollinearity.

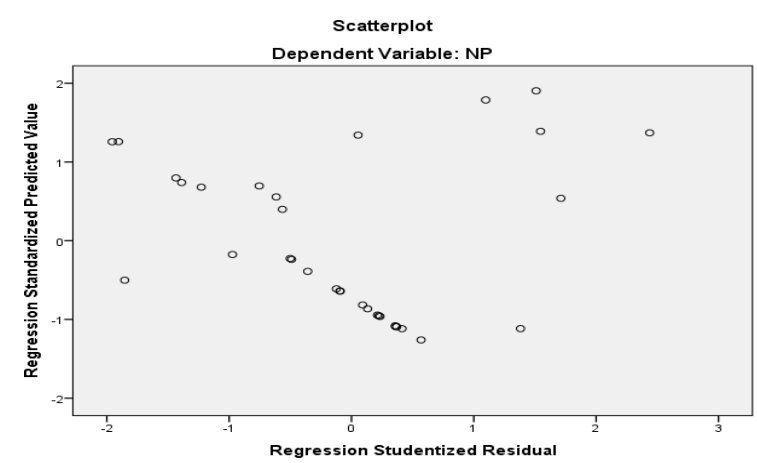

Figure 3. Scatterplot

Based on Figure 3 (scatterplot) it can be seen that there are no points that form a certain pattern and do not converge into one, it can be concluded that there is no heteroscedasticity in the regression model.

Submitted : 14/10/2021 - Accepted : 10/12/2021 - Published : 11/12/2021 
Table 5. Collerations

\begin{tabular}{|c|c|c|c|c|c|c|c|c|c|}
\hline & & & $\begin{array}{c}\text { Kinerja } \\
\text { Keuangan }\end{array}$ & DER & $\begin{array}{c}\text { Kebijakan } \\
\text { Dividen }\end{array}$ & $\begin{array}{c}\text { Current } \\
\text { Ratio } \\
\end{array}$ & Leverage & $\begin{array}{c}\text { Ukuran } \\
\text { Perusahaan }\end{array}$ & $\begin{array}{c}\text { Nilai } \\
\text { Perusahaan }\end{array}$ \\
\hline & & $\begin{array}{l}\text { Correlation } \\
\text { Coefficient }\end{array}$ & 1,000 &,$- 500^{* *}$ & ,143 &, $521^{* * *}$ &,$- 500^{* *}$ &,- 021 &, $371^{*}$ \\
\hline & $\begin{array}{l}\text { Kinerja } \\
\text { Keuangan }\end{array}$ & Sig. (2-tailed) & & ,003 & 427 & ,002 & ,003 & ,906 & \\
\hline & & $\mathrm{N}$ & 33 & 33 & 33 & 33 & 33 & 33 & 33 \\
\hline & & $\begin{array}{l}\text { Correlation } \\
\text { Coefficient }\end{array}$ &,$- 500^{* *}$ & 1,000 &,- 221 &,$- 886^{* *}$ & $1,000^{* *}$ &,- 238 &, 060 \\
\hline & DER & Sig. (2-tailed) & ,003 & & ,216 & ,000 & & 182 & ,741 \\
\hline & & $\mathrm{N}$ & 33 & 33 & 33 & 33 & 33 & 33 & 33 \\
\hline & & $\begin{array}{l}\text { Correlation } \\
\text { Coefficient }\end{array}$ &, 143 &,- 221 & 1,000 &, $425^{*}$ &,- 221 &, $879^{* *}$ &,$- 700^{* *}$ \\
\hline & $\begin{array}{l}\text { Kebijakan } \\
\text { Dividen }\end{array}$ & Sig. (2-tailed) & ,427 & ,216 & . & ,014 & ,216 & ,000 & ,000 \\
\hline & & $\mathrm{N}$ & 33 & 33 & 33 & 33 & 33 & 33 & 33 \\
\hline & & $\begin{array}{l}\text { Correlation } \\
\text { Coefficient }\end{array}$ &, $521^{* *}$ &,$- 886^{* *}$ &, $425^{*}$ & 1,000 &,$- 886^{* *}$ &, $456^{* *}$ &,- 235 \\
\hline \multirow{11}{*}{$\begin{array}{l}\text { Spearman's } \\
\text { rho }\end{array}$} & Current Ratio & Sig. (2-tailed) & ,002 & ,000 & ,014 & . & ,000 & ,008 & , 189 \\
\hline & & $\mathrm{N}$ & 33 & 33 & 33 & 33 & 33 & 33 & 33 \\
\hline & & $\begin{array}{l}\text { Correlation } \\
\text { Coefficient }\end{array}$ &,$- 500^{* *}$ & $1,000^{* *}$ &,- 221 &,$- 886^{* *}$ & 1,000 &,- 238 & 060 \\
\hline & Leverage & Sig. (2-tailed) & ,003 & & ,216 & ,000 & . &, 182 &, 741 \\
\hline & & $\mathrm{N}$ & 33 & 33 & 33 & 33 & 33 & 33 & 33 \\
\hline & & $\begin{array}{l}\text { Correlation } \\
\text { Coefficient }\end{array}$ &,- 021 &,- 238 &, $879^{* *}$ &, $456^{* *}$ &,- 238 & 1,000 &,$- 849^{* *}$ \\
\hline & $\begin{array}{l}\text { Ukuran } \\
\text { Perusahaan }\end{array}$ & Sig. (2-tailed) & 906 & 182 & ,000 & ,008 & 182 & . & ,000 \\
\hline & & $\mathrm{N}$ & 33 & 33 & 33 & 33 & 33 & 33 & 33 \\
\hline & & $\begin{array}{l}\text { Correlation } \\
\text { Coefficient }\end{array}$ &, $371^{*}$ & ,060 &,$- 700^{* *}$ &,- 235 & ,060 &,$- 849^{* *}$ & 1,000 \\
\hline & $\begin{array}{l}\text { Nilai } \\
\text { Perusahaan }\end{array}$ & Sig. (2-tailed) & ,034 &, 741 & ,000 & , 189 & ,741 & ,000 & \\
\hline & & $\mathrm{N}$ & 33 & 33 & 33 & 33 & 33 & 33 & 33 \\
\hline
\end{tabular}

Table 5 shows a significant value on financial performance, dividend policy, current ratio, leverage, firm size greater than 0.05 , so it can be concluded that there is no heteroscedasticity.

Table 6. Dependent Variable

\begin{tabular}{|c|c|c|c|c|c|c|}
\hline \multirow[t]{2}{*}{ ode } & & \multicolumn{2}{|c|}{ Unstandardized Coefficients } & \multirow{2}{*}{$\begin{array}{c}\text { Standardized } \\
\text { Coefficients }\end{array}$} & \multirow[t]{2}{*}{$\mathrm{t}$} & \multirow[t]{2}{*}{ Sig. } \\
\hline & & B & Std. Error & & & \\
\hline & (Constant) & ,001 & ,000 & & 3,438 &, 002 \\
\hline & Kinerja Keuangan & ,001 & ,001 &, 190 & 1,100 & ,281 \\
\hline & DER &, 000 &, 000 &,- 170 &,- 829 & ,415 \\
\hline \multirow[t]{4}{*}{1} & Kebijakan Dividen & $8,247 \mathrm{E}-007$ & 000 & ,033 &, 183 & ,856 \\
\hline & Current Ratio & $-7,547 \mathrm{E}-006$ &, 000 &,- 161 &,- 887 &, 383 \\
\hline & Leverage & $-6,479 \mathrm{E}-005$ &, 000 &,- 177 & $-1,012$ &, 321 \\
\hline & Ukuran Perusahaan & $-4,576 \mathrm{E}-005$ & 000 &,- 682 & $-3,997$ & 000 \\
\hline
\end{tabular}

Submitted : 14/10/2021 - Accepted : 10/12/2021 - Published : 11/12/2021 
Firm value $=0.001+0.001$ financial performance $+0.000 \mathrm{der}+8.247 \mathrm{E}-007$ dividend policy $+(7.547 \mathrm{E}-006)$ current ratio $+(6.479 \mathrm{E}-005)$ leverage $+(4.576 \mathrm{E}-$ $005)$ firm size.

The $\mathrm{t}$-value of the financial performance variable is 1.100 , the t-table value is obtained from the degrees of freedom. The degrees of freedom are $\mathrm{n}-\mathrm{k}=33-6=$ 27 , then the table is 2.05183 . So it can be concluded that $\mathrm{t}$ count $<\mathrm{t}$ table $(1.100<$ 2.05183) which means that financial performance has an effect on firm value. Meanwhile, when viewed from sig 0.281 > 0.05 , financial performance is not significant to firm value.

The $t$ value for the der variable is -0.829 , the $\mathrm{t}$ table value is obtained from the degrees of freedom. The degrees of freedom are $\mathrm{n}-\mathrm{k}=33-6=27$, then the $\mathrm{t}$ table is 2.05183 . So it can be concluded that $\mathrm{t}$ arithmetic $<\mathrm{t}$ table $(-0.829<$ 2.05183) which means Affect the value of the company. Meanwhile, when viewed from sig $0.415>0.05$, but der is not significant to firm value. The t-value of the dividend policy variable is 0.183 , the $\mathrm{t}$ table value is obtained from the degrees of freedom. The degrees of freedom are $\mathrm{n}-\mathrm{k}$ $=33-6=27$, then the table is 2.05183 . So it can be concluded that tu arithmetic < t table $(0.183<2.05183)$ which means that dividend policy has an effect on firm value. Meanwhile, when viewed from sig $0.856>0.05$, the dividend policy is not significant to firm value. The t-value of the current ratio variable is -0.887 , the t-table value is obtained from the degrees of freedom. The degrees of freedom are $\mathrm{n}-\mathrm{k}$
$=33-6=27$, then the $\mathrm{t}$ table is 2.05183 . So it can be concluded that tu arithmetic < t table $(-0.887<2.05183)$ which means that the current ratio has an effect on firm value. Meanwhile, when viewed from sig $0.383>0.05$, the current ratio is not significant to firm value.

The $t$ value of the leverage variable is 1.012 , the $\mathrm{t}$ table value is obtained from the degrees of freedom. The degrees of freedom are $\mathrm{n}-\mathrm{k}=33-6=27$, then the $\mathrm{t}$ table is 2.05183 . So it can be concluded that $\mathrm{t}$ count $<\mathrm{t}$ table $(-1.012<2.05183)$ which means that leverage has an effect on firm value. Meanwhile, when viewed from sig $0.321>0.05$ but leverage is not significant to firm value.

The t-value of the firm size variable is 3.997, the t-table value is obtained from the degrees of freedom. The degrees of freedom are $\mathrm{n}-\mathrm{k}=33-6=27$, then the $\mathrm{t}$ table is 2.05183 . So it can be concluded that $\mathrm{t}$ count $<\mathrm{t}$ table $(-3.997<2.05183)$ which means firm size has an effect on firm value. Meanwhile, when viewed from sig $0.000<0.05$, which means that the size of the company is significant to the value of the company.

\begin{tabular}{|c|c|c|c|c|c|}
\hline $\begin{array}{l}\text { Mod } \\
\text { el }\end{array}$ & $\mathrm{R}$ & R Square & $\begin{array}{l}\text { Adjust } \\
\text { ed R } \\
\text { Square }\end{array}$ & $\begin{array}{l}\text { Std. Error of } \\
\text { the } \\
\text { Estimate }\end{array}$ & $\begin{array}{l}\text { Durbi } \\
\text { n- } \\
\text { Wats } \\
\text { on } \\
\end{array}$ \\
\hline 1 & $\begin{array}{l}, 72 \\
4^{\mathrm{a}}\end{array}$ & $\begin{array}{l}5 \\
5 \\
2 \\
4\end{array}$ & ,414 & $\begin{array}{l}, 0 \\
00 \\
30\end{array}$ & 2,428 \\
\hline
\end{tabular}

The table above shows the Coefficient of Determination analysis produces an Adjusted R Square number of 0.414,

Submitted : 14/10/2021 - Accepted : 10/12/2021 - Published : 11/12/2021 
meaning $41.4 \%$ of the variation in firm value variables which can be explained by the independent variables of firm size, leverage, current ratio, dividend policy, der, and financial performance. While the other $58.6 \%$ are explained by other independent variables that are not included in the study.

\begin{tabular}{|c|c|c|c|c|c|c|}
\hline \multirow{3}{*}{ Model } & & Sum of & $d$ & & $F$ & $\mathrm{Sig}$ \\
\hline & & Squares & $\mathrm{f}$ & Square & & \\
\hline & $\begin{array}{l}\text { Regre } \\
\text { ssion }\end{array}$ &, 000 & 6 & ,000 & & $\begin{array}{l}, 0 \\
0 \\
2^{\mathrm{b}}\end{array}$ \\
\hline \multirow[t]{2}{*}{1} & $\begin{array}{l}\text { Resid } \\
\text { ual }\end{array}$ & ,000 & 26 & ,000 & & \\
\hline & Total &, 000 & $\underline{32}$ & & & \\
\hline
\end{tabular}

The table above shows that the calculated $F$ value is 4.770 and the $F$ table has a significant value of 0.05 while DF1 and DF2 are obtained by the formula DF1 = number of variables $-1=6-1=5$, DF2 $=$ sample - number of variables $=33-5=$ 28 which is 2.56. So that financial performance, earnings, dividend policy, current ratio, leverage, and firm size have a simultaneous significant effect on firm value because $\mathrm{F}$ arithmetic $4.770 \mathrm{u}>\mathrm{F}$ table 2.56 with sig value $0.002<0.05$.

Based on the partial hypothesis test ( $\mathrm{T}$ test) the results show that the $t$ value <ut table $(1.100<\mathrm{u} 2.05183)$ with a significant value of $0.281>0.05$ which means that financial performance has an effect but is not significant to the value of manufacturing companies in the food subsector and drinks that are listed on the Indonesia Stock Exchange in 2018 - 2020. Thus, Ha is rejected while Ho is accepted. The results of this study are in line with previous research by Widyaningrumu
(2014) whose results show that ROA has no significant effect on firm value.

Based on the partial hypothesis test (T test) it was found that the $\mathrm{t}$ value $<\mathrm{t}$ table ($0,829<\mathrm{u} 2,05183$ ) with a significant value of $0.415>0.05$ which means that der has an effect but is not significant on the value of manufacturing companies in the food and food sub-sector. drinks listed on the BEIu in $2018-\mathrm{u}$ 2020. Thus, $\mathrm{Ha}$ is rejected while Ho is accepted. The results of this study are in line with previous research by Mardiyati, et al. (2012) whose results show that debt policy has no significant effect on firm value.

Based on the partial hypothesis test (T test) the results show that the $t$ value <ut table $(0.183<2.05183)$ with a significant value of $0.856>0.05$ which means that dividend policy has an effect but is not significant on the value of manufacturing companies in the food and beverage sub-sector. Yangu was listed on the IDX in 2018 2020. Thus, Hau was rejected while Ho was accepted. The results of this study are in line with previous research by Herawati (2013) whose results show that dividend policy has no significant effect on firm value.

Based on the partial hypothesis test (T test) the results show that the $t$ value $<\mathrm{t}$ table $(-$ $0.887<2.05183$ ) with a significant value of $0.383>0.05$ which means that the current ratio has an effect but is not significant on the value of manufacturing companies in the food and beverage subsector. Drinks listed on BEIu in $2018-\mathrm{u}$ 2020. Thus, $\mathrm{Ha}$ is rejected while $\mathrm{Ho}$ is

Submitted : 14/10/2021 - Accepted : 10/12/2021 - Published : 11/12/2021

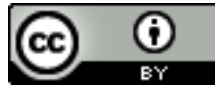

This work is licensed under a Creative Commons Attribution 4.0 International 
accepted. The results of this study are in line with previous research by Stiyarini and Santoso (2016) whose results show that the current ratio has no significant effect on firm value.

Based on a partial hypothesis test ( $T$ test) the results show that the value of $t$ count $<$ $\mathrm{t}$ table $(-1.012<2.05183)$ with a significant value of $0.321>0.05$ which means that leverage has an effect but is not significant on the value of manufacturing companies in the food and beverage subsector. which is listed on the IDX in 2018 $-\mathrm{u}$ 2020. Thus, Ha is rejected while Ho is accepted. The results of this study are in line with the previous research by Analysis (2011)u whose results show that leverage has a positive and insignificant effect on firm value.

Based on the partial hypothesis test (T test) the results show that the $\mathrm{t}$ value $<\mathrm{t}$ table $(-$ $3.997<2.05183)$ with a significant value of $0.000<\mathrm{u} 0.05$ which means that the size of the company has a significant effect on the value of manufacturing companies in the food and food sub-sector. Drinks listed on BEIu in $2018-\mathrm{u}$ 2020. Thus, $\mathrm{Ha}$ is rejected while Ho is accepted. The results of this study are in line with previous research by Putu Mikhy Novari and Putu Vivi Lestari (2016) whose results show that company size has a positive and significant effect on firm value.

\section{CONCLUTION}

Financial Performance Partial but not significant effect on Company Value in Manufacturing Companies in 2018-2020. DERu (Debt on Equity Ratio) has a partial but not significant effect on Company Value in Manufacturing Companies in 2018-2020. Dividend Policy has a partial but not significant effect on Company Value in Manufacturing Companies in 2018-2020. The Current Ratio (CR) has a partial but not significant effect on Company Value in Manufacturing Companies in 2018-2020. Leverage has partial but not significant effect on Company Value in Manufacturing Companies in 2018-2020. Company size partially has a significant effect on Company Value in Manufacturing Companies in 2018-2020. Financial Performance, DER (Debt on Equity Ratio), Dividend Policy, Current Ratio (CR), Leverage, Company Size have an effect on Company Value but Company Size has a significant effect on Company Value in Manufacturing Companies in 2018-2020

\section{REFERENCE}

[1] Rivandi, Muhammad, 2018. "Pengaruh Intellectual Capital Disclosure, Kinerja Keuangan, dan Kepemilikan Manajerial terhadap Nilai Perusahaan". Jurnal Pundi, Sekolah Tinggi Ilmu Ekonomi KBP, Vol. 02, No. 01, Maret 2018.

[2] Berliani, Citra dan Akhmad Ridwan, 2017. "Pengaruh Good Corporate Governance, Kinerja Keuangan, dan Ukuran Perusahaan terhadap Nilai Perusahaan". Jurnal Ilmu dan Riset Akuntansi, Vol. 6, No.3, Maret 2017.

[3] Ilhamsyah, Fendyka Lugman, dkk, 2017. "Pengaruh Kebijakan Dividen, Keputusan Investasi, dan Profitabilitas terhadap Nilai Perusahaan". Jurnal Ilmu dan Riset

Submitted : 14/10/2021 - Accepted : 10/12/2021 - Published : 11/12/2021

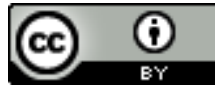

This work is licensed under a Creative Commons Attribution 4.0 International 
Manajemen, Vol. 2, Februari 2017.

[4] Hidayat, Muhammad. 2018. "Pengaruh Manajemen Pajak, Pertumbuhan Penjualan dan Ukuran Perusahaan terhadap Nilai Perusahaan pada Perusahan Manufaktur di BEI Periode 2014- 2016". Jurusan Akuntansi, Ekonomi, Universitas Riau Kepulauan Indonesia, Vol. 2, No. 2, Desember 2018.

[5] Prastuti, Ni Kadek Rai, dkk. 2016. "Pengaruh Struktur Modal, Kebijakan Dividen, dan Ukuran Perusahaan terhadap Nilai Perusahaan pada Perusahaan Manufaktur". E-Jurnal Manajemen Unud, Vol. 5, No. 3, 2016 : 1572-1598.

[6] Dewantari, Ni Luh Surpa, dkk. 2019 "Pengaruh Ukuran Perusahaan dan Leverage serta Profitabilitas terhadap Nilai Perusahaan pada Perusahaan Food and Beverage di BEI". Jurnal Manajemen, Vol. 5, No. 2, Oktober 2019.

[7] Tan, Anita Prastika, 2018. "Pengaruh Struktur Modal, Pertumbuhan Penjualan, Profitabilitas, dan Ukuran Perusahaan terhadap Nilai Perusahaan pada Perusahaan Manufaktur yang terdaftar di BEI". Fakultas Ekonomi dan Bisnis UMP, 2018.

[8] Utami, putri, dkk. 2019. "Pengaruh Current Ratio, Return On Asset, Total Asset Turn Over dan Debt To Equity Ratio terhadap Nilai Perusahaan pada Perusahaan Manufaktur Subsector Property dan Real Estate yang terdaftar di BEI". FEB Universitas Budi Luhur, Vol. 8, No. 1, April 2019.

[9] Hanifah, Ismi Wahyu, 2018. "Pengaruh Current Ratio, Debt To Equity Ratio, Return On Equity, dan
Size terhadap Nilai Perusahaan pada Perusahaan Makanan dan Minuman “ yang terdaftar di BEI Tahun 20132016.

[10] Nengsih, rita. 2020. "Pengaruh Current Ratio, Net Profit Margin, dan Modal terhadap Nilai Perusahaan". Jurnal Humaniora, Vol. 4, No. 1, April 2020.

[11] Mayogi, Dien Gusti. 2016. "Pengaruh Profitabilitas, Kebijakan Dividen dan Kebijakan Utang terhadap Nilai Perusahaan". Jurnal Ilmu dan Riset Akuntansi, Vol. 5, No. 1, Januari 2016

[12] Rudangga, I Gusti Ngurah Gede, dkk. 2016. "Pengaruh Ukuran Perusahaan, Leverage dan Profitabilitas terhadap Nilai Perusahaan". Jurnal Manajemen Unud, Vol. 5, No. 7, 2016

[13] Profitabilitas terhadap Nilai Perusahaan". Jurnal Manajemen Unud, Vol. 5, No. 7, 2016

[14] Kasmir. 2015. "Analisis Laporan Keuangan". Edisi Satu. Jakarta: PT RajaGrafindo Persada

[15] Widyaningrum. 2014. "Pengaruh Debt to Equity Ratio, Return On Equity, Return On Asset dan Ukuran Perusahaan terhadap Nilai Perusahaan (Studi pada Perusahaan Pertambangan yang terdaftar di Bursa Efek Indonesia tahun 20122016)". Jurnal Administrasi Bisnis (JAB), Vol. 57, No. 1

Submitted : 14/10/2021 - Accepted : 10/12/2021 - Published : 11/12/2021 